\title{
SOBRE AS CONCEPÇÕES NORMATIVAS: SINTÁTICA, HILÉTICA E EXPRESSIVA
}

\author{
ABOUT THE CONCEPTIONS OF NORMS: SYNTACTIC, HYLETIC AND \\ EXPRESSIVE
}

\author{
SOBRE LAS CONCEPCIONES NORMATIVAS: SINTÁTICA, HILÉTICA Y \\ EXPRESIVA
}

\begin{abstract}
MAURício DALRI TIMM Do VALLE
Doutor em Direito pela (Universidade Federal do Paraná (UFPR). Professor do Programa de Pós-Graduação Stricto Sensu em Direito da Universidade Católica de Brasília (UCB). Professor de Direito Tributário da Graduação em Direito do Centro Universitário Curitiba (UniCuritiba). Advogado e consultor tributário. Curitiba, Paraná, Brasil. http://lattes.cnpq.br/9184395989012101 / http://orcid.org/0000-0002-7361-595X / mauricio_do_valle@hotmail.com
\end{abstract}

\begin{abstract}
RESUMO
O objetivo do presente artigo é apresentar, por meio de pesquisa bibliográfica, as discussões sobre a ontologia das normas, a partir das concepções de Georg Henrik von Wright e de Carlos Alchourrón e de Eugenio Bulygin, e, também, apresentar as concepções normativas. Dessa forma, as concepções sintática, semântica ou hilética e pragmática ou expressiva são apresentadas com base nas lições dos principais teóricos que se dedicaram ao tema, como, por exemplo, Alchourrón e Bulygin, Pablo Navarro e Jorge Rodriguez, e, também, Daniel González Lagier. Ao final, conclui-se que as prescrições existem a partir da promulgação. Conclui-se, também, que a concepção sintática deve ser afastada por confundir norma com formulação normativa, que a concepção semântica deve responder à pergunta “como diferenciar normas de proposições não-modalizadas?” e, que a concepção pragmática identifica as normas no plano pragmático porque o significado proposicional é o mesmo em asserções, questionamentos e prescrições.
\end{abstract}

Palavras-chave: Concepção sintática. Concepção hilética. Concepção expressiva. Existência. Normas.

\begin{abstract}
The aim of this article is to present, through a bibliographical research, the discussions about the ontology of norms, from the conceptions of Georg Henrik von Wright and Carlos Alchourrón and Eugenio Bulygin, and also to present the normative conceptions. Thus, syntactic, semantic or hyletic and pragmatic or expressive conceptions are presented based on the lessons of the main theorists who dedicated themselves to the theme, such as, for example, Alchourrón and Bulygin, Pablo Navarro and Jorge Rodriguez, and also Daniel González Lagier. In the end, we concluded that the prescriptions exist from the promulgation. We also concluded that the syntactic conception should be removed because it confuses the norm with normative formulation; that the semantic conception should answer the question "how can norms be distinguished from non-modalized propositions?" And that the pragmatic conception identifies the norms in the pragmatic plan because the propositional meaning is the same in assertions, questions, and prescriptions.
\end{abstract}

Keywords: Syntactic conception. Hyletic conception. Expressive conception. Existence. Norms.

\section{RESUMEN}

El objetivo del presente artículo es presentar, por medio de investigación bibliográfica, las discusiones sobre la ontología de las normas, a partir de las concepciones de Georg Henrik von Wright y de Carlos Alchourrón y de Eugenio Bulygin, y también presentar las concepciones normativas. De esta forma, las concepciones sintáctica, semántica o hilética y pragmática o expresiva se presentan con base en las lecciones de los principales teóricos que se dedicaron al tema, como, por ejemplo, Alchourrón y Bulygin, Pablo Navarro y Jorge Rodríguez, y también Daniel González Lagier. Al final, se concluye que las prescripciones existen a partir de la promulgación. Se concluye, también, que la concepción sintáctica debe ser alejada por confundir norma con formulación normativa, que la concepción semántica 
debe responder a la pregunta "cómo diferenciar normas de proposiciones no modificadas?" Y que la concepción pragmática identifica las normas en el plano Pragmático porque el significado proposicional es el mismo en aserciones, cuestionamientos y prescripciones.

Palabras clave: Concepción sintáctica. Concepción hilarante. Concepción expresiva. Existencia. Normas.

\section{SUMÁRIO}

INTRODUÇAO; 1 SOBRE A EXISTÊNCIA DAS NORMAS JURÍDICAS; 2 AS CONCEPÇÕES DE NORMAS JURÍDICAS; 2.1 A concepção sintática; 2.2 A concepção semântica ou hilética; 2.3 A concepção pragmática ou expressiva; CONCLUSÃO; REFERÊNCIAS.

\section{INTRODUÇÃO}

A questão relativa à existência das normas - o chamado problema da ontologia das normas - é tormentosa. Diretamente a ela relacionada, outra questão também enseja uma série de questionamentos. Trata-se daquela relativa às concepções normativas, que tem sido objeto de intenso debate entre os teóricos do direito. Neste artigo, buscamos enfrentar essas duas questões valendo-nos do método hipotético-dedutivo. A partir das lições de GEORG HENRIK VON WRIGHT e das críticas a ele direcionadas por CARLOS ALCHOURRÓn e EUGENIO BULYGIN, examinamos o entendimento de que a existência de normas demanda, necessariamente, um ato de promulgação e a formação da relação normativa, e, também, aquele que identifica como condição suficiente à existência das normas apenas o ato de promulgação. Num segundo momento, apoiados em ALCHOURRón e BULYGIN, em PABLo NAVARRo e JORGE ROdRIGUEZ e em DANIEL GONZÁLEZ LAGIER, partimos para o exame das diversas concepções normativas, tratando, primeiramente, da concepção sintática, criticando-a em razão da identificação, por ela realizada, entre normas e formulações normativas. Posteriormente, examinamos a concepção hilética ou semântica das normas, apontando a grande questão que deve ser resolvida por aqueles que aderem a essa concepção normativa, qual seja, a de bem distinguir as normas das proposições não-modalizadas. E, por fim, tratamos da concepção expressiva ou pragmática, ressaltando que o grande desafio de seus adeptos é diferenciar as prescrições das asserções e dos questionamentos.

\section{SOBRE A EXISTÊNCIA DAS NORMAS JURÍDICAS}

O problema da existência das normas é tratado por VON WRIGHT no capítulo VII de seu "Norm and action", sob o título de "Problema ontológico das normas". Para o filósofo finlandês, 
esse problema é essencialmente "...la cuestión de qué signifique decir que hay (existe) una norma a tal y tal efecto". Sua análise limita-se às prescrições, e sendo assim, a questão que se propõe a responder é a de que significa dizer que uma prescrição existe ${ }^{1}$.

Abramos, aqui, um parêntesis. Lembremos que logo no prefácio de seu "Norm and action", de 1963, vON WRIGHT afirma que a palavra "norma" não é inequívoca, ao escrever que "Es fácil ver que la palabra 'norma' cubre un campo de significados muy heterogéneo"2. O capítulo I de seu "Norm and action" trata, justamente, das "normas em geral". Nele, vON WRIGHT parte da premissa de que a palavra "norma" é utilizada em muitos sentidos e, frequentemente, com um significado pouco claro. Afirma, ainda, que o campo de significação de "norma" não apenas é heterogêneo, como também possui "fronteiras vagas". Isso tornaria a tentativa de criar uma teoria geral das normas, que tratasse de todo o mencionado campo de significação, algo vão ou fútil. Diante disso, a teoria das normas deve ter um alcance restringido. Para a construção dessa teoria restringida das normas, é necessário considerar que os vários significados de "norma" possuem uma relação lógica. A palavra, ao ver de VON WRIGHT não é "ambígua", no sentido ordinário ${ }^{3}$. Nesse capítulo, VON WRIGHT busca, justamente, identificar e caracterizar, ainda que de maneira breve, certos significados da palavra "norma", ou ainda de espécies ou tipos de normas. Começa sua explicação lembrando que um dos significados de "norma" é "lei", e que essa palavra, "lei", usa-se, frequentemente, em, ao menos, três sentidos: i) leis do estado; ii) leis da natureza; e iii) leis da lógica (e das matemáticas). Ao distinguir as leis da natureza das leis do estado, aponta que estas são prescritivas e não têm valor veritativo, enquanto aquelas são descritivas, sendo verdadeiras ou falsas. Num primeiro momento, o contraste prescritivo/descritivo poderia ser utilizado para estabelecer o que são normas daquilo que não o é. Entretanto, a mera identificação do significado de "normativo" com o de "prescritivo" e o de "norma" com "prescrição" é por demais restritivo. Mas não só. Tanto "prescritivo" como "prescrição" são palavras vagas e, ainda, coisas às quais os atributos prescrito/descrito são ambos inapropriados. VON WRIGHT demonstra que às chamadas "leis da lógica" (ou "da matemática”) não se aplicam os adjetivos prescritivo e descritivo, na medida em que tais leis, em vez de descrever ou prescrever o que for, "determinam"4.

\footnotetext{
${ }^{1}$ Norma y acción: una investigación lógica. Tradução de: FERRERO, Pedro Garcia. Madrid: Tecnos, 1970, p. 123.

${ }^{2}$ Norma y acción..., op. cit., p. 17.

3 lbidem, p. 21.

4 Sobre as leis da natureza, afirma o autor: "Las leyes de la naturaleza son descriptivas. Describen regularidades que el hombre cree haber descubierto en el curso de la naturaleza. Son o verdaderas o
} 
Em seguida, VON WRIGHT estabeleceu três espécies principais de normas, que são i) as regras, ii) as prescrições e iii) as diretrizes e, também, três grupos menores, por assim dizer, de particular importância, que se situam entre as espécies principais, de vez que se podem ligar com mais de uma espécie de normas. As normas desse segundo grupo são i) os costumes, ii) os princípios morais e iii) as regras ideais. Não trataremos, aqui, desse segundo tipo de normas, limitando-nos a fazer menção às excelentes sínteses de RICARDO A. GUIBOURG e de CARLOS SANTIAGO NINO ${ }^{5}$.

À primeira espécie de norma, VON WRIGHT denominou de "regra", cujo exemplo típico são as "regras de um jogo" como, por exemplo, o xadrez. Segundo o autor, "jogar um jogo" é uma atividade humana que se desenvolve com a observância de padrões fixos, aos quais se denomina “movimentos”. As "regras do jogo" determinam não só os movimentos, como também o próprio jogo e a atividade de jogá-lo. As "regras do jogo" determinam, portanto, quais são os “movimentos” corretos e, pelo viés do próprio jogar, quais são permitidos. Determinam, também, quais “movimentos" são incorretos e, portanto, proibidos no jogo. Por fim, estabelecem qual é o "movimento" obrigatório quando, em determinada situação específica em que alguém esteja "jogando o jogo", seja ele o único “movimento” correto".

falsas. La naturaleza no obedece, excepto en un sentido metafórico, a estas leyes. Si se descubre una discrepancia entre la descripción y el curso efectivo de la naturaleza, es la descripción y no la naturaleza la que tiene que ser rectificada. Esta es una caracterización superficial de lo que son las leyes de la naturaleza, pero opino que en lo esencial es correcta". Sobre as leis do estado, eis as palavras do autor: "Las leyes del estado son prescriptivas. Establecen reglamentos para la conducta e intercambio humanos. No tienen valor veritativo. Su finalidad es influenciar la conducta. Cuando los hombres desobedecen las leyes, la autoridad que las respalda trata, por lo pronto, de corregir la conducta de los hombres. En ocasiones, sin embargo, la autoridad cambia las leyes; quizá para hacerlas más conformes con las capacidades y exigencias de la 'naturaleza humana"'. Por fim, sobre as leis lógicas ou matemáticas, assim escreve: "Nos planteamos la cuestión de si las leyes de la lógica y de la matemática son descriptivas o prescriptivas. Hemos encontrado que ninguna caracterización resuelve completamente el problema. Podemos llamar a estas leyes descriptivas, pero no en el mismo sentido inequívoco en el que las leyes de la naturaleza son descriptivas. También podemos llamarlas prescriptivas, pero de una forma algo diferente a aquella en que las leyes del Estado son prescriptivas. La comparación de las leyes de la lógica (de la matemática) con las reglas de un juego sugería una nueva caracterización de estas leyes. De acuerdo con esta nueva caracterización, las leyes de la lógica (matemática) ni describen ni prescriben, sino que determinan algo. Independientemente de lo que podemos pensar de esta comparación en otros respectos, podemos convenir en la utilidad de esta caracterización: se acomoda a las leyes de la lógica (de la matemática) mejor que el atributo 'descriptivo' o el atributo 'prescriptivo"' - Ibidem, p. 21-25.

${ }^{5}$ R. GUIBOURG, El fenómeno normativo: acción, norma y sistema. La revolución informática. Níveles del análisis jurídico, p. 64; C. S. Nino, Introducción al análisis del derecho. 2. ed. 14. reimp. Buenos Aires: Depalma, 2007, p. 69-70.

${ }^{6}$ Outros exemplos utilizados pelo autor são as "regras da gramática" e as "regras de um cálculo lógico e matemático" - Norma y acción..., op. cit., p. 26. 
A segunda espécie de normas, das quais fazem parte as "leis do estado", GEORG HENRIK VON WRIGHT denominou "prescrições" ou "regulamentos". As prescrições têm como características distintivas o fato de serem "dadas" ou “ditadas" por alguém, a quem se denomina "autoridade normativa", e direcionadas aos chamados sujeitos normativos. A "autoridade normativa" faz com que sua vontade seja conhecida pelos sujeitos normativos por meio da "promulgação" da norma, e, para dar efetividade à sua vontade, acrescenta à norma uma sanção ou uma ameaça ou um castigo ${ }^{7}$. É essa espécie normativa que ora nos interessa.

A terceira espécie normativa, por sua vez, é chamada, por vON WRIGHT, de "diretrizes" ou "normas técnicas". Grosso modo, são normas que estabelecem os meios que devem ser empregados para alcançar certo fim. Exemplo típico dessa espécie normativa são as "instruções para uso". Esclarece VON WRIGHT que considerará como formulação dessa espécie normativa as orações condicionais, nas quais, em seu antecedente, haja a descrição de algo que se deseja; e, em seu consequente, a de algo que se deve ou não se deve fazer. 0 exemplo dado é "Si quieres hacer la cabaña habitable, tienes que calentarla". Parece-lhe que essa oração não tem cunho nem descritivo e nem prescritivo. Desenvolvendo seu raciocínio, compara a oração do exemplo com a seguinte: "Para hacer la casa habitable, debe calentarse"8. Esta oração que, a seu ver, é inegavelmente descritiva, estabelece que "aquecer a casa" é uma “condição necessária” para torná-la habitável. Enunciados que, como este, indiquem que uma coisa é, ou não é, uma "condição necessária" para outra coisa, são chamados por VON WRIGHT de "enunciados anankásticos”. Uma “oração anankástica”, que se usa para fazer um "enunciado anankástico", exprime uma "proposição anankástica”. Aqui, vON WRIGHT é enfático, ao afirmar que "...sería un error identificar las normas técnicas con las proposiciones anankásticas"'. Entretanto, reconhece que há una conexão lógica entre ambas, que chama de “essencial”. Segundo ele, quando se dá a diretriz de que "se quer tornar a cabana habitável, deve instalar calefação", pressupõe-se, logicamente, que se não houver calefação na cabana, ela não chegará a ser habitável. Essa espécie normativa - “diretrizes” - também não deve ser confundida com as normas denominadas por VON WRIGHT Como "hipotéticas", que são aquelas relativas ao que se deve, ou se pode fazer, diante do surgimento de determinada contingência. Normalmente, as "normas hipotéticas" são formuladas por meio de orações condicionais. O exemplo utilizado pelo autor é "se o cachorro latir, não corra". Percebe-se que a norma que enuncia a oração é uma prescrição. Por vezes, na

\footnotetext{
${ }^{7}$ Ibidem, p. 26-27.

${ }^{8}$ Ibidem, p. 29.

${ }^{9}$ Ibidem, p. 29.
} 
essência das “normas hipotéticas” (prescrições) há uma proposição anankástica. Entretanto, essa conexão entre “prescrição" e “proposição anankástica” não é essencial, e sim, acidental. Observemos o exemplo utilizado por VON WRIGHT para explicar a questão: "¿Por qué no debo correr, si el perro empieza a ladrar? Si corro, el perro puede atacarme. Por eso, si quiero escapar de ser atacado por el perro que ladra, no debo correr"10. Nesse exemplo, a "proposição anankástica" apenas explica a razão pela qual a "prescrição" foi dada. Podemos observar que, mesmo que não houvesse a "diretriz" ou a "relação anankástica”, seria perfeitamente possível prescrever a qualquer pessoa a ordem de "não correr se...". Por fim, o sujeito normativo pode, a partir de seu próprio raciocínio, extrair uma prescrição autônoma, que é distinta das prescrições heterônomas - categóricas ou hipotéticas - lançadas por uma autoridade normativa. Esse argumento é chamado por VON WRIGHT de "inferência prática", e explicado por ele com o seguinte exemplo: "Quiero hacer la cabaña habitable. A menos que tenga calefación, no llegará a ser habitable. Por tanto, tengo que poner calefación"11. Após realizar essa classificação, voN WRIGHT analisa, exclusivamente, as normas por ele denominadas "prescrições", identificando seus “componentes”, “ingredientes”, ou ainda "partes".

Fechamos, aqui, os parêntesis.

O próprio autor afirma que analisará a questão da existência das prescrições, de modo indireto, partindo da ideia associada à ética kantiana de que "Deve implica Pode ${ }_{2}{ }^{12}$; formulando-a, para as prescrições, da seguinte forma: "Que algo sea el contenido de una prescripción entraña que el sujeto de la prescripción pueda $a_{2}$ hacer dicho algo"13. Em seguida, enfrenta a questão relativa ao significado de "implica" no mencionado princípio, deparando-se com a dúvida acerca da natureza da conexão entre norma e habilidade. Diante dessa interrogação, de ser a conexão entre norma e habilidade "lógica” (ou "conceitual”) ou "física" (ou "causal”), conclui pela primeira: o vínculo é conceitual. Continuando seu raciocínio, voN WRIGHT lembra que a visão de que "Deve implica Pode" foi utilizada, certas vezes, como um contra-argumento à opinião de DAVID HUME, de que há uma distinção entre "norma" e "fato" e entre "dever" e "ser". Entretanto, o filósofo finlandês acredita que os supostos conflitos entre as visões de KANT e de HUME são apenas aparentes. E mais: em sua opinião, aqueles que aí os

\footnotetext{
${ }^{10}$ Ibidem, p. 30.

11 Ibidem, p. 29-30.

12 Aqui, é importante explicar a distinção entre "Pode 1 " e "Pode 2 " encontrada na tradução para o espanhol. "Pode 1 " é a tradução do termo inglês "may" e possui um significado deôntico, enquanto "Pode 2 " é a tradução do termo inglês "can” e possui um significado técnico.

${ }^{13}$ Norma y acción..., op. cit., p. 125.
} 
veem padecem do mal de confundir "normas" e "proposições normativas". O princípio de que "Deve implica Pode 2 ", para VON WRIGHT, não enuncia uma relação de implicação entre "norma” e “proposição normativa”, e sim entre “proposições normativas" e "proposições a respeito da habilidade humana". No antecedente (ou premissa), encontra-se a menção de que há uma norma de tal caráter e conteúdo; e, no consequente, a menção de que o conteúdo da norma "pode ${ }_{2}$ " ser feito. Na interpretação de VON WRIGHT, não se pode afirmar a existência de uma norma antes de examinar os fatos relativos à habilidade humana. Assim, as normas seriam "logicamente dependentes" dos fatos relativos à habilidade humana; ou melhor, aquelas, logicamente, pressuporiam estes; ou, ainda, estes seriam um pressuposto daquelas. Nas palavras do filósofo finlandês, "...las normas no pueden existir, o mejor, no pueden llegar a existir, a menos que se cumplan (ya) ciertas condiciones relativas a la habilidade humana"14. E, após esse raciocínio, formula o princípio kantiano, para as "prescrições", da seguinte forma: "Que haya una prescripción que encarece o permite una determinada cosa, presupone que el sujeto (sujetos) de la prescripción pueda $a_{2}$ hacer lo que se encarece o permite"15 (sic). Mas surge, então, a pergunta: o que significa "poder ${ }_{2}$ fazer" ? Refere-se à habilidade ou ao êxito ? Melhor dizendo: significa que o agente "pode ${ }_{2}$ " fazer a espécie de coisa que a norma estabelece ou permite, ou significa que o agente em questão “pode ${ }_{2}$ ", em determinadas ocasiões, fazer a coisa determinada ou permitida ? De acordo com VON WRIGHT “...parece bastante óbvio...” que o "pode ${ }_{2}$ " refere-se à habilidade, relativa a atos genéricos, pois, caso adotada a outra interpretação, estar-se-ia diante de um paradoxo ${ }^{16}$.

Após essa análise, que podemos chamar de "preliminar", vON WRIGHT passa ao exame da aplicação do princípio kantiano de que "Deve implica Pode 2 " às "prescrições”, em relação às quais enuncia que sua existência, ordenando ou permitindo determinada coisa, pressupõe a habilidade do sujeito da norma de fazer a espécie de coisa ordenada ou permitida. Para verificar se essa é uma interpretação aceitável da relação entre prescrição e habilidade, voN WRIGHT vale-

\footnotetext{
14 Ibidem, p. 126.

15 Idem.

16 "Consideremos una persona a la que se le ha ordenado hacer una determinada cosa en una determinada

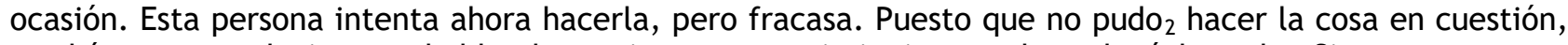
tendríamos que decir que, hablando estrictamente, ni siquiera se le ordenó hacerla. Siempre que una persona intentara seguir, sin éxito, una prescripción, dicha prescripción no existiría (para él). El fracaso en obedecer una norma, la aniquilaría. Pero es evidente que no es así como deseamos conformar nuestra noción de prescripción o norma. Por lo tanto, si queremos hacer del principio Debe entraña Puede 2 un ingrediente de nuestro concepto de norma, tenemos que comprender su 'puede 2 ' en un sentido que sea compatible con el 'no puede 2 ' del fracaso, es decir, debemos entender 'puede ${ }_{2}$ hacer' de forma que implique la habilidad, pero no el éxito, en cada caso individual" - Ibidem, p. 124-127.
} 
se do exemplo no qual um oficial ordena a um soldado que atravesse um rio a nado e o soldado, por sua vez, nega-se a entrar na água, valendo-se do argumento que não "poderia, atravessá-lo a nado ${ }^{17}$. Esse exemplo, em sua opinião, revela duas "tendências conceituais conflitantes". Por um lado, poder-se-ia dizer que, uma vez que o soldado não poderia fazer aquilo que dele era exigido, nem sequer "se poderia," mandá-lo fazer. De outro lado, é possível dizer que existia a ordem, na medida em que se exigiu do soldado fazer algo. Entretanto, vON WRIGHT defende que essas tendências podem ser conciliadas pela observância da distinção entre o "dar" e o "receber" ("tomar”) prescrições. Apesar de se poder dar uma ordem a outro, independentemente de sua habilidade de a realizar, não é possível receber uma ordem de quem quer que seja, a não ser que aquele que a recebe tenha habilidade para a realizar. 0 mesmo ocorre com a permissão. Ainda que se possa dar uma permissão a alguém, independentemente de sua habilidade, esse alguém somente "terá efetivamente a permissão" se puder fazer aquilo que lhe é permitido. A questão que surge é a de se saber como essa divisão, entre "dar" e “receber", afeta a existência das prescrições. Isso porque, como bem ressalta VON WRIGHT, é de certa forma tentador sustentar que a existência das prescrições dependeria apenas da emissão, prescindindo da habilidade do receptor. Segundo ele, entretanto, ainda que a existência da prescrição dependesse somente da emissão, disso não se pode concluir que essa existência é independente das habilidades do receptor ${ }^{18}$.

Retomemos, aqui, a noção de "ação normativa", que é justamente o nome que voN WRIGHT atribui à ação humana por meio da qual as prescrições começam a existir. Questiona-se VON WRIGHT se o "dar a prescrição" é um "ato" ou uma "atividade” e, ainda, se a existência dessa prescrição é o "resultado" ou é uma "consequência” da ação normativa. Em sua visão, o

\footnotetext{
17 "Supongamos que nuestro soldado es juzgado militarmente y acusado de desobediencia. Si no puede justificar su pretensión de no ser capaz de atravesar a nado el río, entonces claramente puede ser sentenciado y castigado por desobediencia. Pero si puede ${ }_{2}$ justificar su pretensión, ies cierto que 'no' puede ${ }_{2}$ entonces ser sentenciado y castigado? El soldado puede, naturalmente, ser tratado de la forma que es característica del castigo y que supone la imposición de algún tipo de dolor o cosa desagradable. Este trato puede incluso describirse correctamente como castigo. Sería un castigo por la manera en que contestó al oficial o a un castigo porque no probó en el momento que no podía ejecutar el acto requerido, es decir, meterse en el agua y permitir así al oficial poner a prueba su habilidad. 0 puede ser castigado porque no ha aprendido a nadar, cuando se suponía que debía haber aprendido a hacerlo durante su adiestramiento. Pero en cualquier caso, para que podamos llamar castigo al trato que recibe y no simplemente maltrato, aquello por lo que se castiga tiene que ser algo que podría ${ }_{2}$ haber hecho, pero no lo hizo. Y dado que, en nuestra hipótesis, el soldado no puede ${ }_{2}$ hacer lo que la orden de atravesar el río a nado exige, no puede $_{2}$ ser 'castigado' por haber desobedecido 'esta' orden. No puede haberla 'desobedecido', porque solo hay 'lugar' para la desobediencia cuando la obediencia es posible. Y la obediencia es posible solamente cuando hay habilidad de hacer lo que se exige" - Ibidem, p. 130.

${ }^{18}$ Ibidem, p. 129-131.
} 
“dar a prescrição" é um ato cuja execução exitosa resulta na existência de uma prescrição. Esses atos terão por consequência os efeitos da prescrição sobre a conduta daqueles a quem ela (prescrição) é direcionada. Nesses "atos" - chamados de "normativos" - assim como em todos os demais, está implicada uma "atividade", que, neste caso específico, é uma "atividade verbal", a qual consiste em enunciar ou promulgar a norma, para os sujeitos normativos, por meio de formulações normativas. Fica claro que, para VON WRIGHT, o "ato de dar a prescrição" é distinto da "atividade verbal implicada no ato", concluindo que a "...mera emisión de oraciones imperativas y el uso de otras formas de lenguaje prescriptivo no establece que un mandato, permiso o prohibición se haya dado, no 'constituye' por sí mismo un acto de mandar, permitir o prohibir"19. Além da atividade verbal, é necessária também a formação da chamada "vinculação normativa" ou, como prefere VON WRIGH, "vinculación bajo norma" entre a autoridade e o sujeito normativo. Para o filósofo finlandês, somente com o estabelecimento dessa vinculação é que a norma passa a existir. A partir desse momento - e até o momento em que se dissolver a vinculação normativa - é possível dizer que a norma está em “vigor”. Ocorre que, com a dissolução da vinculação normativa, a norma, na visão de VON WRIGHT, deixa de existir. Para ele, portanto, a norma apenas existe enquanto estiver em vigor ${ }^{20}$. Na ação normativa, encontra-se

\footnotetext{
${ }^{19}$ Ibidem, p. 131.

20 "...cuando la emisión de una sentencia-mandato 'constituye' un acto de mando, existe a partir de ese momento y durante un tiempo una relación entre el dador y el receptor del mandato, entre el que manda y el que es mandado. También podríamos llamar a esto una 'vinculación normativa' entre las partes. Preferiré llamarlo una 'vinculación bajo norma' entre ambos. También aquí, como en el caso de las promesas, no sería correcto identificar el mandato con esta vinculación bajo norma. Pero es justo decir que cuando el uso del lenguaje prescriptivo conduce a o tiene como resultado el establecimiento de esta vinculación entre una autoridad-norma y algún sujeto (sujetos)-norma, entonces la prescripción se ha dado, el acto normativo se ha ejecutado con éxito y la norma ha cobrado existencia. Las prescripciones no sólo cobran existencia, sino que también dejan de existir. Las prescripciones cesan de ser cuando se disuelve la vinculación bajo norma, que el dar de las prescripciones estableció. La vida de una prescripción es así la duración de la vinculación entre autoridad-norma y uno o varios sujetos-norma. Mientras dura esta vinculación, se dice que la prescripción está en vigor. La existencia de una prescripción no es el hecho, como tal, de que se ha dado, sino el hecho de que está en vigor" - Ibidem, p. 131-132. Sobre a explicação de VON WRIGHT, assim manifestaram-se CARLOS ALCHOURRÓN e EUGENIO BULYGIN: "In von Wright's account two basic conditions are required for the truth of the statement that a norm is, or exists: 1. The giving of the norm by the norm-authority, and 2 . The receiving of the norm by the norm-subject. The 'giving-aspect' ins the normative action performed by norm-authority; it can be an analyzed into two components: 1.1 the promulgation of the norm (which is an essentially verbal activity; it consists of the use of norm-formulations to enunciate the norm), and 1.2. an effective sanction, i.e., explicit or implicit threat of punishment for disobedience to the norm (NA125). For a sanction to bem effective a special condition must be fulfilled by the person (or persons) who act as the norm-authority: this is the (generic) ability to command, which is founded on a 'superior strength of the commander over the commanded' (NA127). But the giving-aspect alone is not enough; the normative action is successful only if it results on the establishment of a normative relationship (or relationship under norm) between the authority and the subject(s). 'When use of prescriptive language leads to or results in the establishment of this relationship
} 
ainda outro componente, qual seja, a "sanção", que poderá ser eficaz ou não - definida por voN WRIGHT como "...una amenaza de castigo, explícito o implícito, por desobediencia de la norma" cuja função é constituir motivo de obediência da norma, nos casos em que ausentes outros motivos de obediência e naqueles em que presentes motivos de desobediência. Essa "sanção" não pode ser estabelecida por qualquer pessoa. Aquele que a estabelece, ou seja, a autoridade normativa, deve ser "mais forte" que o sujeito normativo. Essa “força superior" está ligada à possibilidade ${ }_{2}$ de concretizar as ameaças de castigo que constituem a sanção da norma, caso ela seja desobedecida. Essa, na visão do filósofo finlandês, é a base fática sobre a qual a ordem legal do Estado se baseia ${ }^{21}$.

O entendimento de VON WRIGHT está longe de ser aceito sem questionamentos. ALCHOURRÓN e BULYGIN dedicaram uma obra específica para analisar o problema ontológico das normas. "Sobre la existencia de las normas jurídicas" inicia advertindo que o campo normativo não é homogêneo, havendo muitas espécies de normas e, em razão disso, parece ser questionável que exista apenas um conceito de existência aplicável a todas as espécies normativas. Não apenas isso, mas também é importante observar que os seguidores da tradição normativista provavelmente conceberão a existência das normas de forma diversa daqueles da tradição realista. Para estes, a norma jurídica existe quanto obedecida e utilizada pelos membros do grupo, enquanto para aqueles, a validade é a existência específica da norma, como será visto adiante ${ }^{22}$.

between a norm-authority and some norm-subject(s), then the prescription has been given, the normative act successfully performed, and the norm has come into existence' (NA118). The receiving-aspect being essential form the norm's existence, the norm-subject must b 'receive' the norm. But the reception of the norm does not consist of merely becoming aware of the promulgation of the norm; a norm-subject cannot receive a norm 'unless he can do the enjoined or permitted thing' (NA111). His ability to act according to the norm is a presupposition of norms (NA 110). This presupposition connects the notion of existence with the Kantian principle that 'ought entails can'. According to von Wright norms have a temporal duration. They come into existence with the establishment of the normative relationship and they cease to exist when this relationship dissolves (NA118) [...] So the existence of a norm depends on the existence of a normative relationship between norm-authority and the norm-subject" - von Wright on deontic logic and the philosophy of law, The philosophy of Georg Henrik von Wright, p. 666-667.

21 "La superior fuerza del que manda sobre el mandado es también la base fáctica sobre la que el orden legal del Estado se funda. La existencia de un orden legal es la existencia de relaciones normativas entre autoridades y ciudadanos. Es esencial que las autoridades sean capaces de respaldar sus prescripciones a los ciudadanos con amenazas de castigo en caso de desobediencia. Cuando esta condición no se cumple, el orden legal se derrumba o desintegra, como ocurre cuando una revolución tiene éxito" - Norma y acción..., op. cit., p. 139-142.

${ }^{22}$ Sobre la existencia de las normas jurídicas. Ciudad de México: Fontamara, 1979. (Biblioteca de Ética, Filosofía del Derecho y Política, 39), p. 9-11. 
Lembremos, que nessa obra, ALCHOURRón e BULYGIN cunharam as expressões "normacomunicação", “norma-prescrição" e "norma-sentido" - sobre as quais trataremos no próximo item - para fazer menção a diversas espécies de normas, a partir da analogia com as situações de "comunicação", de "asserção" e de "proposição".

Como parece intuitivo, por serem normas diversas, distintas serão suas condições de existência. ${ }^{23}$ Desse modo, é importante reconhecer procedência à crítica formulada por ambos ao entendimento de VON WRIGHT, na medida em que sua concepção de existência normativa é adequada apenas às "normas-comunicação", nas quais é certa a vinculação normativa em razão da recepção da ordem pelo sujeito normativo, como, por exemplo, as decisões judiciais. Para as demais espécies normativas, a concepção de VON WRIGHT é inservível. ${ }^{24}$ As normas-prescrições, por exemplo, independem da recepção por parte do sujeito normativo. Bastará, para a existência dessa espécie de normas, o ato de promulgação. Para AlChOURRón e Bulygin: “...la promulgación de la norma es la única condición suficiente y necesaria, para su existencia. [...] todo acto (serio) de promulgar una norma [...] da lugar a la existencia de una norma". ${ }^{25}$

23 "Las condiciones de existencia de las normas-comunicaciones, de las normas-prescripciones y de las normas-sentidos son claramente distintas, pero no resulta del todo claro en qué estriban exactamente las diferencias. En lo que sigue trataremos de elucidar estos conceptos con miras a la elaboración de una noción de existencia de normas que sea útil para hablar de la existencia de normas jurídicas. Ahora bien, una de las características típicas de las normas jurídicas en su existencia en el tiempo: las normas jurídicas comienzan a existir en un cierto momento, existen durante un lapso más o menos prolongado y dejan de existir en otro momento. Este carácter temporal de la existencia de las normas jurídicas nos va a servir de criterio de adecuación para la definición del concepto de existencia que estamos buscando; sólo una noción de existencia capaz de dar cuenta de la temporalidad de las normas será considerada satisfactoria a los efectos de este análisis" - Ibidem, p. 17.

${ }^{24}$ Ibidem, p. 19-23.

${ }^{25}$ Ibidem, p. 25-29. Em outro escrito, CARLOS ALCHOURRón e EUGENIO BULYGIN reiteram o posicionamento: "The act of issuing a norm - its promulgation - marks the moment at which a norm begins to exist. It ceases to exist when it is derogated. The derogation of a norm may be tacit or explicit. A norm is tacitly derogated when it comes out of existence by mere expiration of a certain period of time; such is the case with particular norms (particular as regards occasion) or temporal laws (in which it has been stipulated that they should cease at a certain moment). Such norms are rather exceptional; usually a legal norm ceases to exist when it is explicitly derogated by the corresponding norm-authority by means of an act of derogation. The existence of a norm is temporally continuous: a norm is said to be existent from the moment of its promulgation to the moment of its derogation; but the temporal duration of a norm is a mere logical construction. There are no facts (besides the initial fact of promulgation and the final fact of derogation) which would make the statement true that a norm exists during its life-span. There are onluy certain criteria for the beginning and termination of norms. This characterization of temporal existence of norms - which differs significantly from that of von Wright - is in accord with a current linguistic usage in the fields of law. Jurists often say that there is (exists) such-and-such a norm, and all they mean is that this norm has been promulgated (perhaps long ago) and has not yet been erogated. It is a noteworthy fact that legal norms very often outlive their authorities: a general legal norm may exist for a long time after the authority that issued it has disappeared (Laws continue to exist after the death of a King or the dissolution of the parliament by whom they had been enacted. This fact shows that the characterization 


\section{AS CONCEPÇÕES DE NORMAS JURÍDICAS}

$\mathrm{Na}$ teoria do direito, costuma-se identificar três ou quatro concepções sobre as normas. PABLO NAVARRO e JORGE RODRIGUEZ inicial o trato do tema com uma interessante provocação: “If we accept the idea that all languages phenomena have a syntactic, a semantic, and a pragmatic dimension, and that norms are at least expressible in language, we should also accept that these same three dimensions have a correlate in the case of norms". ${ }^{26}$ Ninguém nega que as normas podem, pelo menos, ser formuladas linguisticamente. Há, entretanto, dúvidas sobre as relações entre a linguagem e as normas. Para tratar desse ponto específico, é de grande auxílio conhecer a classificação das normas, à qual fizemos referência acima, realizada por CARLOS ALCHOURRÓN e EUGENIO BULYGIN, em seu "Sobre la existencia de las normas jurídicas", com base em analogia que toma por supedâneo os sucessivos processos de abstração, a partir de uma mesma situação: a comunicação, a asserção e a proposição. A “comunicação” - uso primário da linguagem - é um ato complexo, no qual se encontram envolvidos ao menos dois sujeitos: o emissor, de um lado, e o receptor ou destinatário da mensagem, de outro. Para que a comunicação efetivamente exista, mostram-se necessárias, tanto a emissão, quanto a recepção da mensagem ${ }^{27}$. Caso abstraiamos a recepção da mensagem por parte do destinatário, estaremos diante apenas da emissão da mensagem. Aqui, há uma relação diádica entre o sujeito emissor da mensagem e o significado da expressão linguística. Situação essa denominada de "asserção" ou de "asseveração". Tomaremos, neste momento, “asserção" pelo que "asseverado", ou seja, enquanto enunciado, e não enquanto "ato de asseverar"28. Podemos avançar no processo de

of the continuous existence of a norm in terms of continuity of the normative relationship between the norm-authority and the norm-subjects is not suitable for most legal norms" - von Wright on deontic logic and the philosophy of law, The philosophy of Georg Henrik von Wright, p. 670.

${ }^{26}$ Deontic logic and legal systems. New York: Cambridge University Press, 2014, p. 66

27 "Desde el punto de vista formal, la comunicación es una relación entre por lo menos tres elementos: el hablante, el mensaje (es decir, el significado de la expresión lingüística usada) y el destinatario. Se dirá que la comunicación tuvo lugar cuando el hablante ha emitido una expresión lingüística con un significado determinado y el destinatario percibió la expresión (la oyó o la leyó) y pudo captar su significado, que tiene que ser el mismo para los sujetos involucrados en la comunicación" - Sobre la existencia de las normas jurídicas, p. 14.

28 "Según si ponemos el acento en el sujeto o en el contenido de la aserción, podemos distinguir entre el acto de aseverar llevado a cabo por un sujeto en una ocasión determinada y lo aseverado por el sujeto en esa ocasión. [...] Distinguiremos, en consecuencia, entre la aserción como acto y la aserción como enunciado, sin perder de vista que los dos no son independientes y que el acto de aserción presupone un 
abstração e, mirando, agora, no sujeito emissor, abstrai-lo, centrando nossa atenção apenas no conteúdo significativo de um possível ato de asserção. É a "proposição” a que fazem referência os lógicos ${ }^{29}$. Como com as normas acontece algo similar, ALCHOURRón e BULYGIN cunham os termos especiais “norma-comunicação”, “norma-prescrição” e "norma-sentido”, análogas às situações de “comunicação", “asserção” e "proposição”. Para os autores, as “normas-comunicação” são as situações análogas à comunicação, em que o comunicado não é uma asserção, e sim uma prescrição. Denominam de “norma-prescrição" aquilo que foi prescrito, com o perdão da repetição, por um ato de prescrever, realizado por um sujeito - normalmente, uma autoridade normativa, em uma ocasião determinada. E, por fim, a "norma-sentido", que tem conceito análogo ao de proposição, será uma prescrição possível de um estado de coisas, ou seja, é uma proposição com sentido normativo. ${ }^{30}$

Tendo essa classificação em mente, iniciamos o exame das concepções sobre as normas, propriamente dita. Esse exame é essencial, principalmente porque grande parte das discrepâncias sobre temas fundamentais da teoria do direito - como, por exemplo, a possibilidade de uma lógica de normas, as relações entre as normas e a verdade e, ainda, a existência de normas permissivas - têm origem no fato dos diversos autores partirem de concepções normativas absolutamente diferentes e, até mesmo, incompatíveis ${ }^{31}$.

Um bom ponto de partida encontra-se PABLo EUGENIO NAVARRO ${ }^{32}$ e em DANIEL GonZALEZ LAGIER, que identifica quatro grandes grupos de teses sobre o tema. Além daquelas três concepções - sintática, semântica (hilética) e pragmática (expressiva), mencionadas por JORGE RODRIGUEZ $^{33}$ - insere uma quarta concepção, denominada, por ele, de concepção mista (sintáticosemântica). Em breve síntese, LAGIER expõe que I) na concepção sintática, a norma identifica-se com sua formulação; ii) na concepção semântica (hilética), a norma identifica-se com o

enunciado aseverado y la aserción como enunciado presupone la realización del correspondiente acto de aserción" - Ibidem, p. 15.

29 "La proposición es una entidad abstracta que puede ser caracterizada como el significado de una oración declarativa; desde luego, dos oraciones distintas pueden expresar la misma proposición (cuando tienen el mismo significado), pero la proposición no esta ligada a ninguna oración determinada de ningún lenguaje específico: puede haber proposiciones que no han sido expresadas por ningún lenguaje y no han sido, en consecuencia, nunca aseverada por nadie" - Ibidem, p. 15-16.

${ }^{30}$ Ibidem, p. 16-17.

31 CaRlos AlChOURRón e Eugenio Bulygin, La concepción expresiva de las normas. In: Análisis lógico y derecho. Madrid: Centro de Estudios Constitucionales, 1991, p. 121-122.

32 La eficacia del derecho: una investigación sobre la existencia y funcionamiento de los sistemas jurídicos. Madrid: Centro de Estudios Constitucionales, 1990. (Colección El Derecho y la Justicia, 16), p. 29-40.

${ }_{33}$ Norms, truth, and legal statements, in Neutrality and theory of law. Editado por: BELTRÁN, Jordí Ferrer, MORESO, Jose Juan e PAPAYANNIS, Diego. New York: Springer, 2013, p. 139. 
significado do enunciado com o qual ela é formulada; e iii) na concepção pragmática (expressiva), a norma identifica-se com um ato de fala específico ou com o resultado desse ato de fala. ${ }^{34}$ Tratemos de cada uma delas.

\subsection{A concepção sintática}

$\mathrm{Na}$ “concepção sintática” das normas, cujo desenvolvimento deve-se à influência de opiniões de filósofos como QUINE, as normas identificam-se com os enunciados normativos ou com as formulações normativas. É curioso observar, como bem ressalta LAGIER, que do considerar as normas como enunciados podem resultar “...consequências contraintuitivas” para os estudiosos da teoria da norma e para os juristas em geral, como por exemplo, a de admitir que as normas, por serem entidades linguísticas inscritas em documentos - em papel ou outro material qualquer - ou seja, objetos físicos, possam ser destruídas e deixar de existir. ${ }^{35}$ Temos certeza de que a dificuldade que nós temos em aceitar que uma norma possa ser queimada, por exemplo, é compartilhada por muitos teóricos do direito.

A principal crítica, parece-nos, que pode ser dirigida a essa concepção, é a de que a mesma expressão linguística pode ser utilizada para expressar tanto uma norma quanto uma proposição normativa, como alertam PABLO NAVARRO e JORGE RODRIGUEZ. ${ }^{36}$

Lembremos que GEORG HENRIK VON WRIGHT, em seu “Norm and action", de 1963, identificou a ambiguidade das expressões deônticas, na medida em que uma mesma oração pode ser utilizada para exprimir uma norma ou uma proposição normativa. ${ }^{37}$ Voltemos à questão inicial acerca da distinção entre "norma" e "formulação da norma”. Esta, para GEORG HENRIK VON WRIGHT, é o signo ou o símbolo, ou melhor, o conjunto das palavras usadas para formular uma norma. A essa formulação, em determinados casos, costuma-se chamar "promulgação"38. Ainda tratando desse tema, o filósofo finlandês lembra-se da distinção das "dimensões semânticas"

\footnotetext{
${ }^{34}$ Acción y norma en G.H. von Wright. Madrid: Centro de Estudios Constitucionales, 1995. (Colección El Derecho y la Justicia, 42), p. 344-345.

${ }^{35}$ Ibidem, p. 346.

36 "Norms cannot be identified at a mere syntactic level because the very same linguistic expression can be used to express either a norm (if enacted by an authority) or a norm-proposition - that is, a sentence that describes the existence of a norm (if uttered by someone who is not an authority)" - Deontic logic and legal systems, p. 67

${ }^{37}$ Norma y acción..., op. cit., passim.

${ }^{38}$ A promulgação é o nome que frequentemente se atribui à formulação das prescrições, que são, para GEORG HENRIK VON WRIGHT, um tipo de norma, no qual se enquadra o Direito Positivo, ou, nas palavras do filósofo finlandês, as "leis do estado".
} 
entre "sentido" (conotação, significado) e "referência" (denotação). Aquele, diz respeito à proposição que a sentença descritiva exprime, enquanto este é o fato que faz da proposição, expressa pela sentença descritiva, verdadeira. Entretanto, vON WRIGHT é da opinião de que seria um equívoco examinar a diferença entre "normas" e "formulações das normas", considerando-as como dimensões semânticas. Isso porque as semânticas dos discursos prescritivo e descritivo são diferentes. E, com base nisso, afirma VON WRIGHT que não se deve pensar que as ferramentas conceituais aplicáveis ao discurso descritivo sejam perfeitamente aplicáveis ao discurso prescritivo. De fato, chama-lhe a atenção o fato de que as normas da espécie "prescrições" não são nem a "referência" nem o "sentido" da correspondente "formulação da norma", o que o leva a questionar qual seria a relação entre a "formulação da norma" e a "norma”. Segundo ele - e tratando de prescrições - a "promulgação" seria uma ligação essencial no - ou parte do processo por meio do qual a norma se origina ou passa a existir. Esse seria o uso executivo da linguagem, que é imprescindível para o estabelecimento da relação entre a autoridade normativa e o sujeito normativo. Assim, as "prescrições” dependem da linguagem. Sua existência pressupõe o uso da linguagem nas formulações das normas ${ }^{39}$.

Em seguida, e desconsiderando formulações de normas que sejam gestos ou sinais, voN WRIGHT passa a analisar os "tipos gramaticais" de sentenças particularmente importantes para a linguagem das normas. São elas: i) as sentenças imperativas e ii) as sentenças deônticas ${ }^{40}$. As primeiras, orações no modo imperativo, e as segundas, sentenças que contenham verbos auxiliares deônticos, tais como "deve”, “pode” ou "tem que não”. No que se refere às relações entre as sentenças imperativas e as normas, VON WRIGHT sustenta ser conveniente examiná-las respondendo a duas indagações: i) se as orações imperativas se usam exclusivamente como formulações de normas; e ii) se podem todas as normas ser formuladas por meio de orações imperativas. A primeira pergunta é respondida de forma negativa. Isso porque, segundo o filósofo finlandês, ainda que "imperativo" signifique, em sua origem, o mesmo que mandar, há vários usos desse modo - imperativo - que não têm esse escopo, como, por exemplo, as preces, os pedidos e as advertências. No que diz respeito à segunda pergunta, vem ela acompanhada de um complicador, qual seja, o fato de que o caráter morfológico do modo imperativo é bastante

\footnotetext{
${ }^{39}$ Norma y acción..., op. cit., p. 111-117.

40 É importante ressaltar que esses não são os únicos tipos gramaticais utilizados nas formulações de normas. Nas palavras do próprio autor: "No hay que pensar que las sentencias imperativas y deónticas son los únicos tipos gramaticales de sentencias que se usan en las formulaciones de normas. Sentencias indicativas, que no son sentencias deónticas, se usan también comúnmente para expresar normas. Cuando la norma es una prescripción y su expresión en palabras es una sentencia indicativa (ordinaria), se usa a menudo el tiempo futuro" (sic) - Ibidem, p. 116-117.
} 
confuso na maioria dos idiomas. De fato, para se dizer que um verbo está no modo imperativo é necessário, não raras vezes, examinar o contexto no qual ele está empregado, não sendo bastante a análise da forma gramatical, tão somente. É bem verdade que, usualmente, as sentenças imperativas utilizadas para a formulação de normas o são, principalmente, para enunciar "prescrições”. Isso, entretanto, não quer dizer que as sentenças imperativas sirvam exclusivamente para essa finalidade. ${ }^{41}$

Ao tratar das relações entre as sentenças deônticas e as normas, vON WRIGHT propõe-se a responder às mesmas perguntas enfrentadas por ocasião do exame das relações entre as sentenças imperativas e as normas, ou seja: i) se se usam as sentenças deônticas principal e exclusivamente como formulações de normas; e ii) se podem, todas as normas, ser formuladas em termos de sentenças deônticas. O primeiro alerta de VON WRIGHT é o de que, ao responder a tais perguntas, deve-se atentar para o fato de que tanto a natureza do conceito de sentença deôntica como aquela do conceito de norma, são pouco precisas. A resposta à primeira pergunta, para o autor, é negativa, na medida em que as sentenças deônticas são utilizadas não

\footnotetext{
41 "Las sentencias imperativas que se usan como formulaciones de normas se usan principalmente para enunciar prescripciones. Es hasta cierto punto plausible pensar que toda prescripción de carácter-0, es decir, mandatos y prohibiciones, puede expresarse por medio de una sentencia en modo imperativo aunque parte de la plausibilidad nace de nuestra inclinación a hacer del significado de la sentencia un criterio para llamar imperativo a su modo -. Pero las prescripciones permisivas o prescripciones de carácter-P se expresan comúnmente por medio de sentencias deónticas, usando el verbo 'puede' en combinación con el verbo que expresa la acción permitida. Si tomamos los permisos por prohibiciones dirigidas a un 'tercero', podríamos argüir que pueden formularse indirectamente en términos de imperativos ('no intervenga...', 'permítale hacer...'). Pero aun así, subsiste el hecho de que los permisos, cuando se dirigen directamente al titular, se expresan normalmente por medio de sentencias-'puede'. Hay, sin embargo, una especie de sentencias imperativas cuya función normal parece ser la de enunciar permisos. Me refiero a sentencias de la forma 'haga esto-y-esto, si quiere', o 'haga esto-y-esto, por favor'. Ocasionalmente, las sentencias imperativas de la forma categórica 'haga esto-y-esto' expresan también permisos y mandatos o prohibiciones. Si cuando voy andando por la calle y llego a la esquina el semáforo indica 'cruce ahora', la norma (prescripción) que se me dirige con estas palabras es un permiso para cruzar la calle y no un mandato de que lo haga. Sería pedante decir que un permiso está formulado incorrectamente porque está en el modo imperativo. Pero parece plausible considerar las sentencias imperativas de la forma categórica 'haga esto-y-esto', cuando se usan para enunciar permisos, como formas abreviadas o elípticas de sentencias imperativas hipotéticas: 'Haga esto-y-esto, si lo desea'. Así, pues, la luz del semáforo 'cruce ahora' dirigida a los peatones, es la abreviatura de 'cruze ahora, si lo desea'. Aunque las sentencias imperativas, en tanto que formulaciones de normas, se usan principalmente para enunciar las normas que llamamos prescripciones, sería un error pensar que se usan, en tanto que formulaciones de normas exclusivamente para ese propósito. Decir 'si quieres hacer la cabaña habitable, entonces caliéntala', no es gramaticalmente menos correcto que decir 'si quieres hacer la cabaña habitable, entonces debes calentarla'. Ambas sentencias se entendería ordinariamente que significan lo mismo. No sería correcto decir que con la primera sentencia se da un mandato y con la segunda una regla relativa a los medios para un fin. La función del modo imperativo en 'si quieres hacer la cabaña habitable, entonces caliéntala', y en 'si empieza a llover, entonces cierra la ventana', es diferente. La primera sentencia imperativa expresa una norma técnica, la segunda una prescripción (mandato, orden) hipotética" - Ibidem, p. 111-114.
} 
somente para formulações normativas, como também para enunciar relações anankásticas enunciados que indiquem que uma coisa é, ou não é, uma “condição necessária” para outra coisa - e também como "enunciados normativos", sobre os quais trataremos adiante. Essa questão específica - da ambiguidade das sentenças deônticas - remete-nos ao exame da lógica das normas e da lógica das proposições normativas, e que, de acordo com VON WRIGHT, é uma das grandes contribuições de CARLOS ALCHOURRón e de EUGENIO BULYGIN para a filosofia ${ }^{42}$. Ao enfrentar a segunda pergunta, diz ser razoável pensar que sua resposta é afirmativa. Isso porque, em seu entender, as "sentenças deônticas" possuem uma "capacidade semântica” muito mais rica, enquanto formulações de normas, que as sentenças imperativas, por dois motivos. 0 primeiro deles: pela ausência de uma forma peculiar de "imperativo permissivo", que corresponde à palavra deôntica "pode". E, por fim: pelo fato de que, diferentemente do que ocorre com as sentenças imperativas, o uso das sentenças deônticas não se restringe à formulação de "prescrições", mas sim de todo e qualquer tipo de norma ${ }^{43}$.

Examinemos, agora, aquilo que VON WRIGHT chamou de "enunciado normativo". 0 enunciado normativo, que é uma sentença descritiva, tem por escopo "dar uma informação" sobre o “caráter" e o “conteúdo" de determinada norma, ou seja, se determinada ação é permitida, proibida ou obrigatória ${ }^{44}$. Esse enunciado será verdadeiro ou falso, e seu "fundamento veritativo" será uma resposta verdadeira à pergunta do porquê a ação em questão deve, pode, ou tem que ser realizada. A resposta poderia ser a de que existe uma norma que permite, proíbe ou obriga a realizar aquela ação. Assim, o "fundamento veritativo do enunciado normativo" é a existência dessa norma. A proposição de que uma determinada norma existe chama-se "proposição-norma”. Os fundamentos veritativos tanto dos "enunciados normativos" quanto das “proposições-norma” são determinados “fatos", como, por exemplo, o fato de a norma realmente existir. Essa questão remete-nos ao estudo da existência das normas ou, ainda, ao chamado "problema ontológico das normas" 45.

Por fim, é importante, antes de encerrarmos este item, lembrar que a distinção entre formulação normativa e proposição normativa abriu as portas para o desenvolvimento da lógica das proposições normativas por parte de CARLOS ALCHOURRóN. O próprio VON WRIGHT ressalta a

\footnotetext{
${ }^{42}$ Prólogo, in Análisis lógico y derecho, p. XI e XII.

${ }^{43}$ Norma y acción..., op. cit., p. 115-117.

${ }^{44}$ Nas palavras do autor: "Un enunciado normativo, en términos esquemáticos, es un enunciado que tiene como resultado que algo deba o pueda o tenga que no hacerse (por algún agente o agentes, en alguna ocasión o en general, incondicionalmente o si determinadas condiciones se cumplen)" - Ibidem, p. 120.

45 Ibidem, p. 119-121.
} 
importância das contribuições de CARLOS ALCHOURRón e de EUGENIO BULYGIN, por lançarem luzes à necessidade de contar-se com lógicas distintas para tratar das normas e das proposições normativas ${ }^{46}$. Em 1969, seis anos após a publicação de “Norm and action”, CARLOS ALCHOURRóN publicou o artigo "Logic of norms and logic of normative propositions", no qual desenvolve as bases, não de um novo sistema de lógica deôntica (lógica de normas), e sim de um novo sistema de lógica das proposições normativas - por ele denominada de lógica normativa - ou seja, de proposições que dizem se uma norma foi ditada. Ainda que a lógica das proposições normativas pressuponha a lógica de normas - assim como esta pressupõe a lógica proposicional - com ela (lógica de normas) não se confunde. Nesse artigo, ALCHOURRón pretende demonstrar que a lógica das proposições normativas traz consigo, ao menos, três esclarecimentos: identificar as ambiguidades presentes na utilização de termos como o "permitido" e o "obrigatório", tanto na linguagem corrente quanto no discurso jurídico; caracterizar algumas propriedades dos sistemas normativos, tais como a coerência e a completude, os quais não podem ser formulados de maneira adequada na lógica de normas; e demonstrar que, apesar de ser altamente problemática a interpretação dos operadores reiterados, na lógica deôntica, esses conceitos (de operadores reiterados) são frequentemente utilizados no discurso jurídico ${ }^{47}$.

\footnotetext{
${ }^{46}$ Ao fazer menção ao artigo "Logic of norms and logic of normative propositions", publicado originalmente em 1969, na "Logique et Analyse", n. 47, e, posteriormente, republicado sob o título "Lógica de normas y lógica de proposiciones normativas", in Análisis lógico y derecho, p. 25-49, de autoria de CARLOS ALCHOURRÓN, assim se manifesta VON WRIGHT: "Deseo mencionar aquí separadamente unas pocas contribuciones de las muchas de Alchourrón y Bulygin, que me impresionan como particularmente importantes. La primera tiene que ver con la distinción entre normas y proposiciones normativas. La distinción misma había sido señalada hacía ya mucho tiempo y es bien conocida. Pero, a menudo, su importancia ha sido minimizada o mal interpretada. También filósofos que la elaboraron cuidadosamente no han visto con claridad la cuestión de si la lógica deóntica es una lógica de las normas 'mismas' o de las proposiciones que dicen que hay (existen, han sido dictadas) tales y cuales normas. Así, por ejemplo, en Norma y Acción, yo pensaba que la lógica deóntica era una lógica de las proposiciones normativas en las que se 'reflejan' rasgos lógicos de las normas genuinas. Esta era una visión confusa e insatisfactoria del asunto. Lo que Carlos Alchourrón hizo en el trabajo mencionado y, conjuntamente con Eugenio Bulygin, elaborara en Normative Systems y en varios artículos posteriores, fue subrayar la necesidad de contar con lógicas separadas para los dos tipos de entidades (norma, proposición normativa). Fueron, además, los primeros a desarrollar una lógica especial para las proposiciones normativas. Uno puede tener algunas reservas acerca de la forma como esto fue hecho. Pero nadie puede discutir la importancia de la empresa misma. Tiene consecuencias de gran alcance, por ejemplo, para el tratamiento de dos dificultades notorias en la teoría tradicional del derecho, es decir, la posibilidad de 'lagunas' y contradicciones en los sistemas normativos. Lo que los autores han escrito acerca de esta problemática me parece ser de suma importancia. Una lógica de las proposiciones normativas permite también distinguir entre tipos de permisiones que no pueden ser diferenciados fácilmente dentro de una 'lógica deóntica' de tipo corriente. el status de la permisión es, como se sabe, un tópico controvertido en la teoría jurídica tradicional. Las contribuciones de Alchourrón y Bulygin a su clarificación son notables aportes" - Prólogo, in Ibidem, p. XII. ${ }^{47}$ Lógica de normas y lógica de proposiciones normativas. In: Análisis lógico y derecho. Madrid: Centro de Estudios Constitucionales, 1991, p. 25 et seq.
} 
Firmada a premissa de que as normas devem ser diferençadas da sua formulação normativa, remanesce, ainda, a questão: a que entidades podemos chamar de normas, e, ainda, qual sua relação com a linguagem. Sobre essa questão, há duas concepções básicas sobre as normas: a concepção hilética (ou semântica) e a concepção expressiva (ou pragmática).

\subsection{A concepção semântica ou hilética}

A “concepção semântica" ou "hilética" das normas demandará um pouco mais do nosso tempo. E, aqui, entenderemos a necessidade da explicação inicial sobre a classificação de normas realizada por ALCHOURRón e BULYGIN. Isso porque, como veremos, os partidários dessa concepção normativa, geralmente, entendem as normas jurídicas no sentido de "normassentido". Lembremo-nos de que as normas podem ser analisadas em dois componentes: um descritivo (de um estado de coisas ou de uma ação) e outro prescritivo (componente normativo). As discussões iniciam-se justamente no componente normativo, como alertam ACHOURRón e BULYGIN. ${ }^{48} \mathrm{Na}$ concepção hilética, o componente normativo é o significado do enunciado por meio do qual a norma é formulada. Já em 1979, ALCHOURRón e BULYGIN trataram da concepção hilética de normas, identificando-a como a adotada por numerosos lógicos, principalmente por aqueles que trabalham com modelos semânticos, como KRIPKE, HINTIKKA e KANGER. Aqui, explicam essa concepção como aquela na qual o "especificamente normativo" se dá já no nível semântico, sustentando haver proposições nas quais o aspecto normativo seria ínsito ao conteúdo conceitual. ${ }^{49}$ Posteriormente, em 1981, ALCHOURRón e BULYGIN aprofundam o exame da concepção hilética, explicando, em seu artigo "The expressive conception of norms", que as normas seriam

\footnotetext{
48 “Casi todos los filósofos están de acuerdo en que las normas pueden ser analizadas en dos componentes: un componente descriptivo y un componente normativo. $Y$ si bien es cierto que no hay un completo acuerdo acerca de la cuestión de saber cómo ha de ser caracterizado el componente descriptivo, para la mayoría se trata de un estado de cosas o de una acción. No hay mayores discrepancias sobre este punto, a pesar del hecho de que diferentes autores usan diferentes nombres: vgr. frástico (Hare), contenido normativo (von Wright, Weinberger), radical sentencial (Stenius), tópico (Ross) o sustrato modalmente no diferenciado (Kelsen). Problemas más serios surgen tan pronto volvemos nuestra atención hacia el componente normativo; aquí pueden distinguirse dos puntos de vista conflictivos que dan lugar a dos concepciones de normas radicalmente diferentes" - Normas y lógica: Kelsen y Weinberger sobre la ontologia de las normas. In: Análisis lógico y derecho. Madrid: Centro de Estudios Constitucionales, 1991, p. 251.
}

${ }^{49}$ Sobre la existencia..., op. cit., p. 38. 
entidades parecidas com as proposições, ou seja, seriam o significado das orações normativas ${ }^{50}$. Nesse mesmo sentido, os autores manifestaram-se, anos mais tarde, em $1985^{51}$.

Ainda no que se refere à concepção hilética, há dois pontos que devem ser mencionados. 0 primeiro diz respeito ao fato de que, nessa concepção, as normas são independentes da linguagem, ainda que somente possam ser expressas por meio dela. Isso quer dizer que há normas existentes que, eventualmente, não foram, ainda, formuladas, e, talvez, não venham a ser formuladas jamais. Entretanto, o fato de as normas serem independentes da linguagem não quer dizer que sejam independentes das proposições descritivas, como visto, lembrando que essas nada têm a ver com as proposições normativas ${ }^{52}$. 0 segundo, diz respeito ao fato de que, entre os filósofos do direito que aderem a essa concepção de normas, encontramos aqueles que, a exemplo de GEORGES KALINOWSKI, entendem que às normas podem ser atribuídos valoresverdade, enquanto outros, como WEINBERGER, rechaçam esse entendimento.

Aqui, é importante mencionar o entendimento de PABLO NAVARRO e de JORGE RODRIGUEZ que, partindo da premissa de que para os adeptos da concepção semântica as normas são um certo tipo de proposição (proposições deônticas), devem eles - os partidários dessa concepção -

50 “Para la 'concepción hilética' las normas son entidades parecidas a las proposiciones, esto es, significados de ciertas expresiones, llamadas oraciones normativas. Una oración normativa es la expresión lingüística de una norma y la norma es el significado de una oración normativa en el mismo sentido en que la proposición es considerada como el significado (sentido) de una oración descriptiva. Pero las oraciones normativas, a diferencia de las oraciones descriptivas, tienen 'sentido prescriptivo': ellas no indican que algo 'es' de una cierta manera, sino que 'debe' o 'no debe' o 'puede ser' (hecho)" - La concepción..., op. cit., p. 122.

51 "Para la concepción hilética el componente normativo forma parte del contenido conceptual de la norma; se trata de un operador que - operando sobre una oración descriptiva - hace surgir una oración normativa. La norma es el significado de esta nueva oración (normativa) en el mismo sentido en que una proposición es considerada como el significado de una oración descriptiva. Lo peculiar de las oraciones normativas (Normsätze en la terminología de Weinberger) es que tiene un significado prescriptivo: no dicen que algo es, sino que algo debe (o puede) ser" - Normas y lógica: Kelsen y Weinberger..., op. cit., p. 251.

52 "En esta concepción las normas son independientes del lenguaje; aunque sólo pueden ser expresas por medio del lenguaje, su existencia no depende de expresión lingüística alguna. Hay normas que no han sido formuladas (aún) en ningún lenguaje y que tal vez no serán formuladas nunca. Una norma es, en esta concepción, una entidad abstracta, puramente conceptual. Pero las normas no son independientes de las proposiciones descriptivas: son el resultado de una operación sobre tales proposiciones. Así en una norma, por ejemplo, 'Op', encontramos dos componentes: una proposición descriptiva p y un operador normativo 0 , pertenecientes los dos al contenido conceptual de la norma. En este sentido los operadores normativos son similares a los operadores aléticos modales y una norma es una proposición en el mismo sentido en que de una proposición modal como $\mathrm{Np}$ se dice que es una proposición. Las normas han de ser distinguidas de las proposiciones normativas, es decir, de las proposiciones descriptivas que afirman que $p$ es obligatorio (prohibido o permitido) conforme a una cierta norma o un conjunto no especificado de normas. Las proposiciones normativas - que pueden ser consideradas como proposiciones acerca de conjuntos o sistemas de normas - también contienen términos normativos como «obligatorio», «prohibido», etc., pero esos términos tienen un sentido puramente descriptivo"- La concepción..., op. cit., p. 122-123. 
explicar como se diferenciam as normas das proposições não-modalizadas. Lembremos que a orações deônticas são aquelas nas quais se encontram os termos “permitido", "proibido” e "obrigatório". Tanto normas quanto as proposições não-modalizadas possuem significados. A primeira, significado prescritivo; enquanto as outras, significado descritivo. ${ }^{53}$ De acordo com os autores, a forma mais plausível para distinguir as normas das proposições não-modalizadas seria em termos da semântica dos mundos possíveis, algo que não analisaremos em razão de em muito transbordar as pretensões deste artigo.

Por fim, encerremos o exame da concepção hilética, mencionando o resumo elaborado por LAGIER, que a caracteriza com as seguintes teses: i) as normas são o significado prescritivo das formulações normativas; ii) os operadores deônticos possuem "capacidade semântica", na medida em que atuam no nível semântico; iii) as normas existem independentemente da linguagem; e iv) as normas entendem-se como "normas-sentido" 54.

\subsection{A concepção pragmática ou expressiva}

Passemos, então, ao exame da “concepção pragmática” ou "expressiva” de normas. Aqui, dar-nos-emos conta da importância do estudo dos atos de fala. De saída, é importante firmar que; para os adeptos dessa concepção normativa, existem apenas as "normas-prescrição" e as “normas-comunicação”, não havendo que se falar em “normas-sentido”. Isso porque, há filósofos do direito e morais - como BEntham, Austin, Kelsen, Ross, HARE, JöRgensen, SCHILICK, HANSSON, RaZ etc. - que negam a ideia de "proposição prescritiva”, chegando ao ponto de, aqui, identificar uma "contradição entre termos", entendendo que a norma está diretamente ligada a determinado uso da linguagem ${ }^{55}$. Assim, não haveriam normas de nível semântico. As normas apareceriam apenas no plano pragmático ${ }^{56}$. ACHOURRÓN e BULYGIN, para explicar essa concepção, lembram, inclusive, da doutrina da força ilocucionária, de JOHN AUSTIN. Segundo eles, nessa

\footnotetext{
${ }^{53}$ Deontic logic and legal systems, p. 69-70.

${ }^{54}$ Acción..., op. cit., p. 348.

55 Carlos Alchourrón e Eugenio Bulygin, Normas y lógica..., op. cit., p. 251; dos mesmos autores, La concepción..., op. cit., p. 126.

56 "Para la concepción expresiva, en cambio, las normas son el resultado del uso prescriptivo del lenguaje. Una oración que expresa una misma proposición puede ser usada en diferentes ocasiones para hacer cosas distintas: para aseverar (afirmar), interrogar, ordenar, conjeturar, etc. El resultado de esas acciones será una aserción, una pregunta, una orden o una conjetura. Sólo en el nivel pragmático del uso del lenguaje surge la diferencia entre aserciones, preguntas, órdenes, etc. No hay tal diferencia en el nivel semántico" - Ibidem, p. 123.
} 
concepção a “...característica específica de lo normativo está en el uso prescriptivo del lenguaje" 57 .

Aqui, é importante analisar uma das funções da linguagem que não se amolda nos “...espécimes quimicamente puros" dos usos da linguagem, na expressão de IRVING COPI, que são as funções informativa ${ }^{58}$, expressiva ${ }^{59}$ e diretiva ${ }^{60}$. Lembremos, são raros os casos em que a linguagem é utilizada apenas em umas das três funções mencionadas. ${ }^{61}$ Exemplos são a "função cerimonial", formada por um misto das funções expressiva e diretiva, como ocorre em celebrações, e, ainda, a "função operativa" ou "performativa" da linguagem. Esta última merece menção especial, no entender de COPI, justamente por adaptar-se menos à divisão tripartida dos usos da linguagem. 0 uso da linguagem em sua função operativa ou performativa

\footnotetext{
${ }^{57}$ Sobre..., op. cit., p. 38-39.

${ }^{58}$ Quanto á função informativa: “A linguagem é empregada em sua "função informativa” quando tem por escopo transmitir informações, mediante afirmações e negações. É o discurso utilizado para realizar descrições de estados de coisas ou fenômenos. Essa a razão pela qual se adjetiva essa função, também, como "descritiva". JOHN AUSTIN, entretanto, faz um alerta sobre o que ele chama de "falácia descritiva", lembrando que nem todos os enunciados verdadeiros ou falsos são descrições. Embora pareçam descrições, são manejados para indicar as circunstâncias em que se formula, as restrições às quais se submete e, por fim, a maneira pela qual deve ser tomado o enunciado. Em razão disso, prefere utilizar o termo "constatativo", que é um neologismo derivado do galicismo "constatar", em lugar de "descritivo" MAURÍCIO DALRI TIMM DO VALLE - Princípios constitucionais e regras matrizes de incidência do Imposto sobre Produtos Industrializados - IPI. São Paulo: Noeses, 2016.

${ }^{59}$ Sobre o tema: "Nos casos em que a linguagem é utilizada para comunicar e exteriorizar sentimentos e emoções, ela está exercendo sua "função expressiva". É comum encontrarmos a linguagem em sua função expressiva na poesia. Mas não apenas nela. Orações a Deus, xingamentos e juras de amor são exemplos de linguagem nessa função. COPI adverte que a "expressão" pode ser analisada sob dois prismas. 0 primeiro deles, quando aquele que se vale da linguagem expressiva o faz para si próprio, por exemplo, quando rezamos na solidão da noite. Nesse caso, não há qualquer intenção em despertar sentimentos semelhantes em outrem. Expressamos o sentimento na intimidade do nosso ser. 0 segundo, por sua vez, ocorre quando aquele que se vale da linguagem procura entusiasmar o leitor ou o ouvinte, em suma, o interlocutor, fazendo com que ele compartilhe seu sentimento ou estado de ânimo. O objetivo é inspirar" - MAURícıo DALRI TIMM DO VALLE - Princípios constitucionais e regras matrizes de incidência do Imposto sobre Produtos Industrializados - IPI. São Paulo: Noeses, 2016.

${ }^{60}$ Sobre a função diretiva: "Ao empregarmos a linguagem com o objetivo de induzir a realização ou a abstenção de uma atividade, estamos diante de sua "função diretiva" ou "prescritiva". Geralmente, ordens e pedidos são exemplos do uso diretivo da linguagem. Ressaltamos o fato de que se a diretiva ou a prescrição não alcançar o êxito desejado, isso não the retira o seu caráter. Como veremos, a forma gramatical não é, por si só, um indicador seguro de estarmos diante de uma prescrição. Assim, nem sempre orações no modo imperativo serão diretivas. Da mesma forma, nem sempre que nos deparemos com frases que contenham palavras deônticas, como "obrigatório", "proibido" e "permitido", estaremos diante de uma diretiva. Aqui, é importante lembrarmo-nos da distinção entre a função prescritiva ou diretiva da linguagem e a espécie normativa batizada por GEORG HENRIK VON WRIGHT de prescrições, e alertar o leitor para que não as confunda" - MAURíCIO DALRI TIMM DO VALLE - Princípios constitucionais e regras matrizes de incidência do Imposto sobre Produtos Industrializados - IPI. São Paulo: Noeses, 2016.

61 "A tríplice divisão proposta é elucidativa e valiosa, mas não pode ser mecanicamente aplicada, porque quase toda a comunicação ordinária exemplificará, de um modo provável, em maior ou menor grau, os três usos da linguagem" - Introdução à lógica, p. 50.
} 
pressupõe, como adverte GENARO CARRIó, a existência de um sistema de regras que determine que, por meio do pronunciamento daquelas palavras, certo ato está sendo realizado. Ou, como diz CARLOS SANTIAGO Nino, pronunciar certas palavras, em determinadas condições, implica realizar a ação a que essas palavras se referem. Em síntese: as palavras constituem o ato em si. ${ }^{62} \mathrm{O}$ emprego da linguagem nessa função é muito comum, por exemplo, nas cerimônias de casamento ou na elaboração de testamentos. É possível identificar a utilização da linguagem nessa função a partir das chamadas “elocuções de desempenho”, que são aquelas que, em determinadas circunstâncias, desempenham a ação relatada ou transmitida. Nessas elocuções, encontram-se "verbos atuantes". ${ }^{63}$ No direito, o uso "performativo" ou "operativo" da linguagem possui tão significativa importância que seu estudo merece aprofundamento. Aqui, examinaremos a doutrina de JOHN AUSTIN, em seu "How to do things with words", com o detalhamento que nos parece condizente com este subitem. ${ }^{64}$

Ao final da Conferência VII, AUSTIN afirma ser aquele o momento de afinar a reflexão a respeito das circunstâncias que cercam o "emitir uma expressão". Aqui, rotula o grupo de sentidos no qual o "dizer algo" deve ser sempre "fazer algo", ou seja, o "dizer algo" com o sentido pleno de "dizer", e estabelece que o "dizer algo": i) é um "ato fonético", ou seja, consistente no ato de emitir certos ruídos, cuja expressão é um "phone”; ii) é um "ato fático", enquanto ato de emitir ruídos de certo tipo, pertencentes a determinado vocabulário, respeitando uma certa construção, em conformidade com uma determinada gramática, adotando uma certa entonação, cuja expressão é um "pheme"; e, por fim, iii) é um "ato rético", consistente no utilizar o "pheme", ou suas partes constituintes, com um sentido e uma referência - que tomados conjuntamente equivalem a significado - mais ou menos definidos, cuja expressão é um "rheme". Observemos que, para realizar um "ato fático" é necessário que se realize um "ato fonético". ${ }^{65}$ AUSTIN chama o "ato de dizer algo" de "ato locucionário" (“locutionary act”). E é justamente ao estudo desses atos que as Conferências VIII e IX, de superior importância, dedicam-se. Nessas conferências, AUSTIN explicita as noções de "ato

\footnotetext{
${ }^{62}$ I. COPI, Introdução à lógica. 2. ed. Tradução de: CABRAL, Álvaro São Paulo: Mestre Jou, 1978, p. 52-53. G. CARRIÓ, Notas sobre derecho y lenguaje. 5. ed. Buenos Aires: Abeledo Perrot, 2006, p. 20-21; C. S. NiNo, Introducción al análisis del derecho, p. 64,

${ }_{63}$ “ Um verbo atuante é aquele que denota uma ação que, em condições adequadas, é tipicamente desempenhada mediante o uso desse verbo na primeira pessoa. Exemplos óbvios de verbos atuantes são 'aceitar', 'aconselhar, 'desculpar-se', 'batizar', 'parabenizar', 'oferecer', 'prometer' e 'sugerir'” - I. COPI, Introdução..., op. cit., p. 52-53.

${ }^{64}$ Utilizaremos, aqui, a tradução para o espanhol - Cómo hacer cosas con palabras. Tradução de: CARRIÓ, Genaro e ERABOSSI, Eduardo A. 11. Reimp. Barcelona: Paidós, 2014.

${ }^{65}$ Ibidem, p. 140 e $142-145$.
} 
locucionário", de "ato ilocucionário" e de "ato perlocucionário". 0 “ato locucionário" é o próprio ato de dizer algo, ou seja, equivale a exprimir certa oração. Um “ato ilocucionário”, por sua vez, é o ato realizado ao dizer algo, que muito difere de realizar o ato de dizer algo. Esses são atos que possuem determinada "força" convencional, tais como informar, ordenar, advertir etc. ${ }^{66}$ Essas duas espécies de atos - “locucionário" e “ilocucionários” - pressupõem convenções. É preciso lembrar, também, ao tratar dos "atos ilocucionários”, que nem sempre as consequências e efeitos produzidos são os desejados, e, ainda, dos casos em que efeitos e consequências desejados não são alcançados. Por isso é que, aqui, Austın invoca a distinção entre "tentativa" e "êxito". O terceiro tipo é o chamado "ato perlocucionario" ou "perlocução". Nestes casos, o ato de dizer algo produzirá certas "consequências" ou "efeitos", intencionais ou não, sobre os sentimentos, pensamentos ou ações do auditório, do emissor da expressão ou, até mesmo, de terceiros, tais como convencer, persuadir, dissuadir, confundir etc. ${ }^{67}$

Para essa concepção, as normas são essencialmente ordens.

A explicação de PABLo NAVARRo e JORGE RodRIGUEZ é esclarecedora. Segundo eles, as proposições podem ser utilizadas para se fazer uma asserção, para formular uma questão ou para dar um comando. Geralmente, esses diferentes atos são diferenciados por meio da utilização de símbolos auxiliares, tais como “?” ou “!”. Entretanto, tais símbolos não afetam o sentido da expressão nas quais eles aparecem, de modo que a identificação de se tratar de uma asserção, de um questionamento ou de uma prescrição (norma) apenas é possível no plano pragmático da linguagem. ${ }^{68}$ Observemos o esclarecedor exemplo utilizado por BRUNO PERIOLO ODAHARA:

Exemplificando: a proposição “o relógio está sobre o criado-mudo", conforme o uso adotado, serve para afirmar que o relógio está sobre o criado-mudo; para perguntar se o relógio está sobre o criado-mudo; para mandar que o relógio esteja sobre o criado-mudo, e assim por diante. 0 modo como o sujeito utiliza a linguagem e emite a proposição resta evidenciado, contudo, quando se apõe o

\footnotetext{
${ }^{66}$ Aqui, por acreditarmos que isso transbordaria, em muito, os limites desta tese, deixamos de aprofundar o exame da estrutura dos atos ilocucionários, desenvolvida por JOHN SEARLE, em seu clássico "Actos de habla", de 1969, bem como não realizaremos o exame da classificação dos atos ilocucionários em indiretos e diretos, como também não trataremos da subdivisão dos diretos em "representativos", em "diretivos", em "comissivos", em "expressivos" e em "declarações" (representativas e não representativas), limitando-nos a remeter o leitor para a excelente obra de JUAN JOSÉ ACERO, EDUARDO BUSTOS e DANIEL QUESADA - Introducción a la filosofía del lenguaje. 6. ed. Madrid: Cátedra, 2010 (Colección Teorema), p. 218-224.

${ }^{67}$ Cómo..., op. cit., p. 141-154 e 155-166.

${ }^{68}$ Deontic logic and legal systems, p. 68-69.
} 
sinal de pontuação de interrogação ao final da frase, diferenciando "o relógio está sobre o criado-mudo" de "o relógio está sobre o criado-mudo?". Destarte,

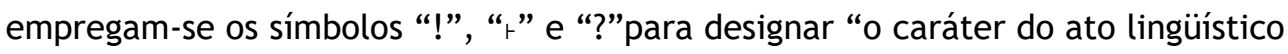
realizado pelo sujeito emissor (não especificado)", seja uma prescrição de $p$ (“!p”), uma asserção de p (“^ p”) ou uma pergunta se é o caso de p (“?p”). Notese que os referidos signos são "meros indicadores do que o emissor faz quando profere certas palavras, porém, eles não contribuem para o significado (isto é, para o conteúdo conceitual) das palavras usadas", tal qual o sinal de interrogação nada agregou quanto à proposição supra, apenas informou que pragmaticamente - se tratava de um questionamento. ${ }^{69}$

E, para finalizarmos o trato da questão, busquemos, novamente, a excelente síntese de LAGIER, para o qual, são teses da concepção expressiva das normas: i) as normas não existem com independência da linguagem; ii) as normas são resultados de específicos atos de fala prescritivos; iii) seu componente normativo é um operador com “capacidade pragmática”, e não semântica; iv) as normas são "normas-prescrição" e “normas-comunicação"; e v) as normas não possuem valores verdade/falsidade. ${ }^{70}$

\section{CONCLUSÃO}

Não parece difícil concluir que a palavra "norma” é ambígua. Como demonstraram ACLHOURRÓN e BULYGIN, diversas são as espécies normativas - "norma-comunicação”, "normaprescrição" e “norma-sentido" - e distintas são suas condições de existência. Desse modo, é importante reconhecer procedência à crítica formulada por ambos ao entendimento de vON WRIGHT, na medida em que sua concepção de existência normativa é adequada apenas às “normas-comunicação”, nas quais é certa a vinculação normativa em razão da recepção da ordem pelo sujeito normativo, como, por exemplo, as decisões judiciais. Para as demais espécies normativas, a concepção de VON WRIGHT é inservível. As normas-prescrições, por exemplo, independem da recepção por parte do sujeito normativo. Bastará, para a existência dessa espécie de normas, o ato de promulgação.

No que se refere às concepções normativas, parece-nos, desde logo, que à concepção sintática pode ser dirigida a crítica de que a mesma expressão linguística pode ser utilizada para

\footnotetext{
${ }^{69}$ Das normas aos sistemas normativos em Eugenio Bulygin. Dissertação de Mestrado em Direito da UFPR. Curitiba: UFPR, 2011, p. 39

${ }^{70}$ Acción..., op. cit., p. 350.
} 
exprimir tanto uma norma quanto uma proposição normativa. Há tempos é reconhecida a ambiguidade das orações deônticas.

No que se refere à concepção hilética ou semântica - que é aquela à qual aderimos tendo em vista que nos parece que as normas são o significado prescritivo das formulações normativas. Entretanto, ainda carece de explicação como se diferenciam as normas das proposições não-modalizadas. Lembremos que a orações deônticas são aquelas nas quais se encontram os termos "permitido", “proibido" e "obrigatório". Tanto normas quanto as proposições não-modalizadas possuem significados. A primeira, significado prescritivo; enquanto as outras, significado descritivo. Como as diferenciar ainda é uma incógnita.

Por fim, na concepção expressiva ou pragmática, as normas são essencialmente ordens. $\mathrm{E}$, tendo em vista que as proposições podem ser utilizadas para se fazer uma asserção, para formular uma questão ou para dar um comando, apensa seria possível diferenciar as normas (comandos) das asserções e dos questionamentos no plano pragmático da linguagem. Seriam as normas resultados de específicos atos de fala prescritivos.

\section{REFERÊNCIAS}

ACERO, Juan José; BUSTOS, Eduardo; QUESADA, Daniel. Introducción a la filosofía del lenguaje. 6. ed. Madrid: Cátedra, 2010 (Colección Teorema).

ALCHOURRÓN, Carlos e BULYGIN, Eugenio. La concepción expresiva de las normas. In: Análisis lógico y derecho. Madrid: Centro de Estudios Constitucionales, 1991, p. 121-153.

]

ALCHOURRÓN, Carlos e BULYGIN, Eugenio. Normas y lógica: Kelsen y Weinberger sobre la ontologia de las normas. In: Análisis lógico y derecho. Madrid: Centro de Estudios Constitucionales, 1991, p. 249-265.

ALCHOURRÓN, Carlos e BULYGIN, Eugenio. Sobre la existencia de las normas jurídicas. Ciudad de México: Fontamara, 1979. (Biblioteca de Ética, Filosofía del Derecho y Política, 39).

ALCHOURRÓN, Carlos e BULYGIN, Eugenio. Von Wright on deontic logic and the philosophy of law. In: SCHILPP, Paul Arthur e HANN, Lewis Edwin. (Editors.). The philosophy of Georg Henrik von Wright. Illinois: La Salle, 1989, p. 665-693 (The library of living philosophers, v. 19).

ALCHOURRÓN, Carlos. Lógica de normas y lógica de proposiciones normativas. In: Análisis lógico y derecho. Madrid: Centro de Estudios Constitucionales, 1991, p. 25-49.

AUSTIN, John. Cómo hacer cosas con palabras. Tradução de: CARRIÓ, Genaro e ERABOSSI, Eduardo A. 11. Reimp. Barcelona: Paidós, 2014. 
CARRIÓ, Genaro. Notas sobre derecho y lenguaje. 5. ed. Buenos Aires: Abeledo Perrot, 2006. COPI, Irving M. Introdução à lógica. 2. ed. Tradução de: CABRAL, Álvaro São Paulo: Mestre Jou, 1978.

GUIBOURG, Ricardo A. El fenómeno normativo. Acción, norma y sistema. La revolución informática. Niveles del análisis jurídico. Buenos Aires: Editorial Astrea, 1987. (Colección Filosofía y Derecho).

LAGIER, Daniel González. Acción y norma en G.H. von Wright. Madrid: Centro de Estudios Constitucionales, 1995. (Colección El Derecho y la Justicia, 42).

NAVARRO, Pablo E. La eficacia del derecho: una investigación sobre la existencia y funcionamiento de los sistemas jurídicos. Madrid: Centro de Estudios Constitucionales, 1990. (Colección El Derecho y la Justicia, 16).

NAVARRO, Pablo. E. e RODRIGUEZ, Jorge L. Deontic logic and legal systems. New York: Cambridge University Press, 2014.

NINO, Carlos Santiago. Introducción al análisis del derecho. 2. ed. 14. reimp. Buenos Aires: Depalma, 2007.

ODAHARA, Bruno Periolo. Das normas aos sistemas normativos em Eugenio Bulygin. Dissertação de Mestrado em Direito da UFPR. Curitiba: UFPR, 2011.

RODRIGUEZ, Jorge. Norms, truth, and legal statments, in Neutrality and theory of law. Editado por: BELTRÁN, Jordí Ferrer, MORESO, Jose Juan e PAPAYANNIS, Diego. New York: Springer, 2013, p. 127-146. (Law and philosophy library, 106).

VALLE, Maurício Dalri Timm do. Princípios constitucionais e regras-matrizes de incidência do Imposto sobre Produtos Industrializados - IPI. São Paulo: Noeses, 2016.

VON WRIGHT, Georg Henrik. Norma y acción: una investigación lógica. Tradução de: FERRERO, Pedro Garcia. Madrid: Tecnos, 1970.

Recebido em: 17/04/2017 / Revisões requeridas em: 16/06/2017 / Aprovado em: 20/06/2017

\section{COMO CITAR O ARTIGO (ABNT)}

VALLE, Maurício Dalri Timm do. SOBRE AS CONCEPÇÕES NORMATIVAS: SINTÁTICA, HILÉTICA E EXPRESSIVA. Revista Eletrônica do Curso de Direito da UFSM, Santa Maria, RS, v. 12, n. 2, p. 593-619, ago. 2017. ISSN 1981-3694. Disponível em:

<https://periodicos.ufsm.br/revistadireito/article/view/26709>. Acesso em: dia mês. ano.

doi:http://dx.doi.org/10.5902/1981369426709. 